\title{
Are Mixtec Forgetting Their Plants? Intracultural Variation of Ethnobotanical Knowledge in Oaxaca, Mexico
}

\author{
Juan Carlos Aparicio Aparicio ${ }^{1}{ }^{\oplus}$, Robert $^{\text {A. }}$ Voeks $^{2}$, And \\ Ligia Silveira Funch ${ }^{1}$
}

1 Departamento de Ciências Biológicas, Universidade Estadual de Feira de Santana, Feira de Santana, Bahia, Brazil

${ }^{2}$ Department of Geography \& the Environment, California State University, Fullerton, CA, USA

*Corresponding author; e-mail: charly_jan92@ @otmail.com

\begin{abstract}
Are Mixtec Forgetting Their Plants? Intracultural Variation of Ethnobotanical Knowledge in Oaxaca, Mexico. Erosion of ethnobotanical knowledge in indigenous communities has been reported increasingly in recent decades. This study quantitatively and qualitatively analyzed the variation of ethnobotanical knowledge in communities of the high Mixtec subregion. We interviewed 64 Mixtec about edible and medicinal plants. We evaluated the knowledge (names and knowledge of use) and the active application of the use among people of different ages, gender, education level, migrants, and non-migrants. In general, increasing age, female gender, decreasing formal education, and non-migration are positively correlated with the knowledge and use of plants. The most alarming finding concerns the knowledge of the Mixtec names of plant-people under 30 years old no longer know them. We envision a process of transition and adaptation of the knowledge and uses of plants, but inevitably enormous ethnobotanical knowledge is quickly disappearing along with the Mixtec language.
\end{abstract}

\begin{abstract}
¿Los mixtecos están olvidando sus plantas? Variación intracultural del conocimiento etnobotánico en Oaxaca, México. La erosión del conocimiento etnobotánico en las comunidades indígenas se ha informado cada vez más en las últimas décadas. Este estudio analizó cuantitativa y cualitativamente la variación del conocimiento etnobotánico en comunidades de la subregión Mixteca alta. Entrevistamos a 64 mixtecos sobre plantas comestibles y medicinales. Evaluamos el conocimiento (nombres y conocimiento de uso) y la aplicación activa del uso entre personas de diferentes edades, género, nivel educativo, migrantes y no migrantes. En general, el aumento de la edad, el género femenino, la baja educación formal y la no migración se correlacionan positivamente con el conocimiento y uso de las plantas. El hallazgo más alarmante se refiere al conocimiento de los nombres mixtecos de las plantas: las personas menores de 30 años ya no los conocen. Visualizamos un proceso de transición y adaptación del conocimiento y usos de las plantas, pero inevitablemente un enorme conocimiento etnobotánico está desapareciendo rápidamente junto con el idioma mixteco.
\end{abstract}

Keywords: Loss of traditional knowledge, Wild food plants, Wild medicinal plants, Mixtec region, Ethnobotany

Received: 22 July 2021; accepted: 26 October 2021;

published online 29 November 2021 


\section{Introduction}

Plants are the natural resource most used by human beings. Ethnobotanical studies in diverse indigenous communities around the world have recorded a great variety of uses of plants-for medicine, food, ritual, fuel, and play, among others. The knowledge and practices that indigenous communities harbor about plants (and other natural resources) are collectively known as traditional indigenous knowledge (TIK). This knowledge constitutes a practical understanding of the environment that is rooted in place, transmitted orally, or by imitation, is often more empirical than theoretical, and is subject to daily reinforcement (Voeks 2018, p. 220). Traditional knowledge is naturally in constant flux (Ellen and Harris 2000). However, over the past few decades it has been changing much faster (Cox 2000; Vandebroek and Balick 2012), often due to the globalization processes reaching even the most isolated communities. These effects are largely negative (Case et al. 2005), and there is the real possibility that much of this accumulated knowledge of nature will disappear in one or two generations (Voeks 2018, pp. 218-240).

The fate of declining traditional knowledge is shared by indigenous languages. By the early 1900 s, it was suggested that of the 6,000 languages spoken in the world, half had disappeared (Krauss 1992). In turn, it has been estimated that by the year 2101, half of the languages that are known will disappear (Harrison 2008). Languages are closely related to traditional knowledge systems, and because they encode TIK, it is predictable that when a language dies, the entire arsenal of knowledge is lost as well (Cámara-Leret and Bascompte 2021).

In recent years, several studies have focused on evaluating the decline in traditional plant knowledge (Albuquerque et al. 2011; Case et al. 2005; Voeks and Leony 2004). The measurable variables have been age, gender, education, economic prosperity, kinship, ethnic interaction, as well as distance from urban centers (Almeida et al. 2012; Eyssartier et al. 2008; Gómez-Baggethun and Reyes-García 2013; Lozada et al. 2006). Age is the variable most associated with traditional knowledge change. Some studies have reported that age is directly related to the erosion of traditional plant knowledge (Begossi et al. 2002; Case et al. 2005; Estomba et al.
2005; Hanazaki et al. 2000), whereas others have argued that knowledge is not directly affected by age (Giovannini et al. 2011; Vandebroek and Balick 2012) and that, perhaps, young people are molding knowledge about plants with new labels (names) and meanings (Voeks and Leony 2004). Thus, comparing the knowledge of older and younger people may not necessarily reveal knowledge erosion (Quinlan and Quinlan 2007).

In Mexico, the variation of traditional knowledge has been studied from a unique plant (Cilia-López et al. 2008), from plants for specific treatments (Smith-Oka 2008), to various groups of plants: medicinal, edible, and weeds (Albino-García et al. 2011; Beltrán-Rodríguez et al. 2014; Carbajal-Esquivel et al. 2012; Estrada-Castillón et al. 2012). In general, these studies have not shown great concern about the erosion of knowledge, with the exception of Smith-Oka (2008), who described loss of knowledge of plants with reproductive purposes in Nahua women from Veracruz, Mexico.

In the Mexican state of Oaxaca, a multicultural area with great wealth in medicinal and edible plants (Cruz-Pérez et al. 2021; Pascual-Mendoza et al. 2021), the variation and loss of ethnobotanical knowledge in the Zapotec culture has been evaluated (Pascual-Mendoza et al. 2021; Saynes-Vásquez et al. 2013; Saynes-Vásquez et al. 2016), as well as the influence of biomedicine on the traditional knowledge of medicinal plants in the Zapotec culture (Giovannini et al. 2011). In Mixtec culture in particular, Aguilar-Santelises and del Castillo (2015) explored the relationship of Mixtec traditional knowledge with demographic and socioeconomic attributes. They concluded that although traditional knowledge is widespread in the studied communities, there is declining knowledge and use of plants due to acculturation. The following study was developed in a municipality in the Mixtec region of the state of Oaxaca. We especially wanted to understand the traditional knowledge of a previously chosen sample of plant species, with respect to people of different ages, sex, educational level, as well as migrants vs. non-migrants. The indigenous municipality was suitable for the study because despite being small, it has educational institutions from basic to higher level, and currently is undergoing an accelerated modernization process. We explored this question with quantitative 
data that has been supplemented with compiled qualitative information.

\section{Methods}

\section{Study AREA}

The Mixtec region encompasses part of three states in southern Mexico: Puebla, Guerrero, and Oaxaca. The Mixtec or $\tilde{N} u u$ savi (people of the rain), speak the Mixtec language of the Otomangue linguist family and are the third group with the largest number of speakers of a native language in Mexico (INALI 2010). Based on altitude, the region is divided into three important subregions: the "Mixteca de la Costa" or Ñudeui (foot of the sky); the "Mixteca Baja" or Ñuine (hot land), and the "Mixteca Alta" or N $\tilde{N} u$ Savi $\tilde{N} u h u$ (divine place).

Our study was conducted in 9 of the 10 communities of the municipality of San Miguel el Grande located to the west of the Mixtec high subregion (UTM 14Q 646,792 West and $1,885,242$ North; Datum WGS84), in the state of Oaxaca, Mexico (Fig. 1). The community known as Colonia Lázaro Cardenas ("General Lázaro Cardenas" in Fig. 1) was established in 1998 as a result of a territorial dispute with another neighboring municipality and was not included in the study. The communities included in the study surround the municipal headquarters and the most distant one is approximately $4.7 \mathrm{~km}$ away in a straight line. All communities are undergoing modernization (evident in the community infrastructure and in the traditional lifestyle of the people), but the municipal headquarters is the most important urbanized center and concentrates the political-administrative institutions.

Despite the fact that in the Mixtec high subregion, there are areas that are highly degraded by soil erosion, the communities in the study area have a continuous vegetation cover, especially in the higher altitude forests; however, it is important to note that urbanization has profoundly modified the landscape in all localities. Although the municipality does not have formal conservation areas, reforestation is carried out in several communal sites.

The municipality has an average annual temperature of $12^{\circ} \mathrm{C}$; annual precipitation varies between 800 and $1,000 \mathrm{~mm}$ (INEGI 2005).
The Köppen classification, modified by García (2004), is temperate subhumid, with rains and high humidity in summer and dry winters. The rainy season runs from May to October and the dry season from approximately October to May. Vegetation is dominated by pine-oak forest (Pinus spp. and Quercus spp.).

The Mixtec in the study area are a mountain people. In 2010, there were 2,223 women and 1,904 men (INEGI 2010). In the same year, there were $904(22.34 \%)$ people living in extreme poverty (INEGI 2015). The municipality has schools for basic education (primary [9], secondary [3], and high school [1]), and a Higher Technological Institute.

Two important features of San Miguel el Grande need to be noted. The first is social development. Educational institutions, especially the institute of higher education that started in 2004, have brought a large number of people from different regions of the state, which has had a significant impact on the community. As a result, there are three general groups of people in the population: those who have finished their education and have been employed by the government; those who have taken advantage of the considerable demand for goods and services and started a business; and those who have resisted change and thus maintained their traditional way of life, that is, by continuing to cultivate their milpa (corn, beans, squash, and broad beans). Some of this latter group can be employed as day laborers in the communities or they may temporarily emigrate to big cities to work, especially to the United States.

The local traditional medical system is also noteworthy. Despite the existence of pharmacies, corner stores stocked with medicines, government health clinics, and a basic community hospital in the neighboring municipality $(5.5 \mathrm{~km}$ away), the Mixtec of San Miguel el Grande continue to use magic and natural resources to cure common diseases and also supernatural illnesses. Simple aches and pains such as headaches can be cured with a short-lived massage with a chicken egg, with or without herbs. The disturbances of the senses or idiopathic muscular pains are generally attributed to the famous nahual or tono (links between people and animals (nahual) in which what happens to one affects the other, or links with rays or eddies (tono) in which one person can make another 

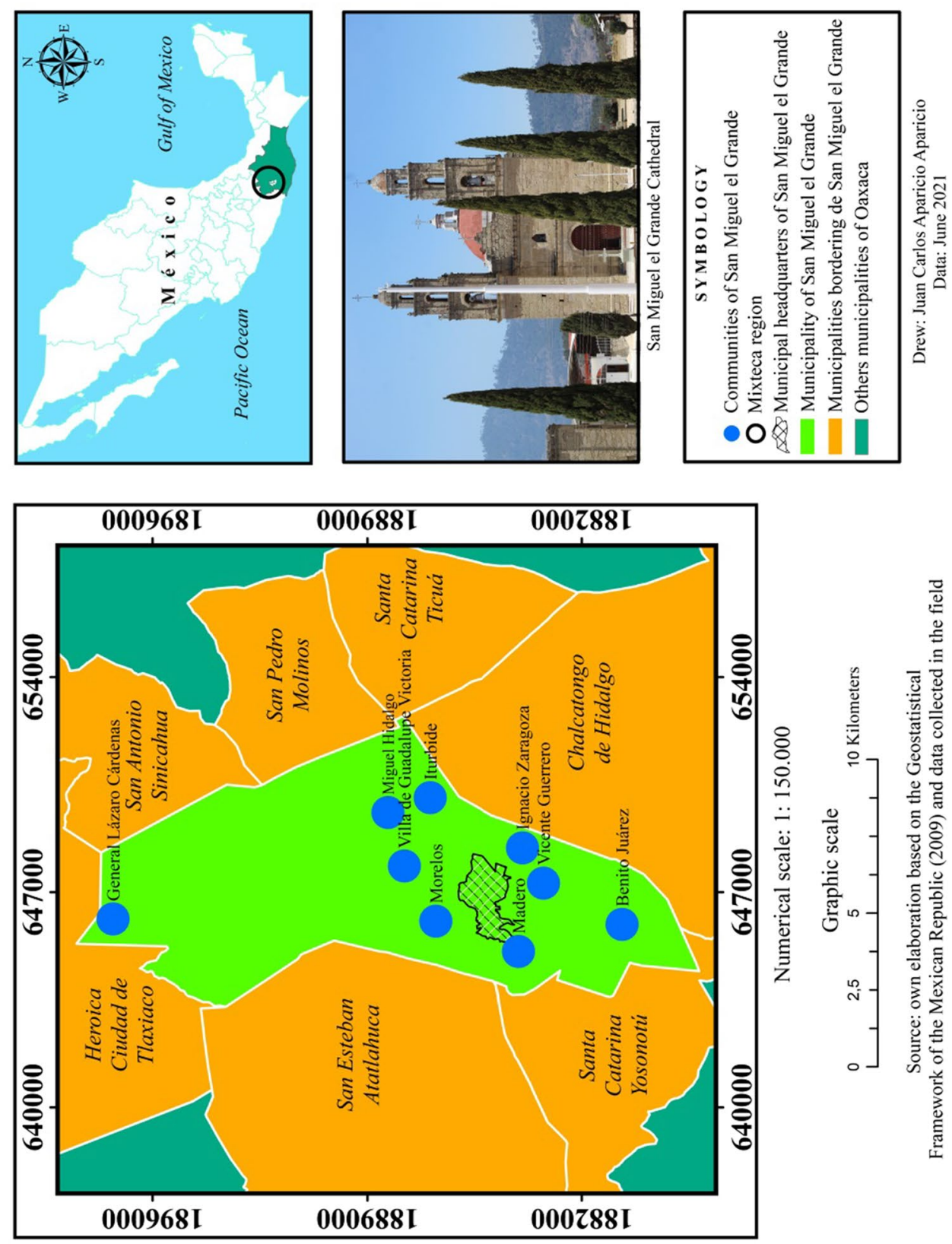

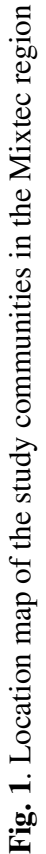


suffer through rays or eddies). Healing consists of special rituals, and includes various herbs, rainwater, trees that have been affected by lightning and ball lightning, among others. Some diseases or ailments, varied and rare, are thought to be caused by disturbing a particular site or "sacred place." The cure is essentially based on a good "healing ritual" that can include plants, animals, food, drinks, and chicken eggs, the purpose of which is to "collect the spirit" of the person who has remained in the place that was disturbed. Finally, there are groups of plants (to a lesser extent animals and fungi) that are used to treat different diseases and conditions.

\section{Data Collection and Analysis}

The research took into account the principles of the Code of Ethics of the Latin American Society of Ethnobiology (Cano-Contreras et al. 2015) and the Code of Ethics of the International Society of Ethnobiology (ISE 2006), as well the previous consensus with municipal authorities of the study area. Informed consent was obtained verbally from all participants prior to the study. The photographs were taken with prior authorization and the interviews with minors were carried out with the consent of the person and the guardian, who was present throughout the interview.

We interviewed a total of 64 people, men and women, aged 16 to 88 . The analysis consisted of interviews concerning 17 specific plants: 11 with medicinal use, 10 with edible use, and 4 with both medicinal and edible uses (Table 1). The plants were obtained from an ongoing study on the uses of plants in San Miguel el Grande. According to our preliminary data, Mixtec people in the study area know more than 150 medicinal plants (including introduced species) and approximately 88 edible plants (including various parts of the plants, not including "domestic plants"). However, many of them are known only to curanderos (healers) or older people with extensive and likely idiosyncratic ethnobotanical knowledge (see Vandebroek 2010). Since our study sought to include people from all communities, of different ages and with different occupations, we chose a small number of plants so that our interviews were quick and effective (we thought that some people might not participate if the list was too extensive). These particular 17 species were also chosen

TABle 1. SAMPLE OF Edible AND MEdicinal PLANTS USED IN THE STUDY

\begin{tabular}{|c|c|c|}
\hline Scientific name & Mixtec name & Uses \\
\hline Tillandsia bourgaei Baker & Ximu & Edible \\
\hline Oxalis corniculata $\mathrm{L}$ & Nduxa iso & Medicinal, edible \\
\hline Lopezia racemosa $\mathrm{Cav}$ & Yua xnté́ & Edible \\
\hline Heterotheca inuloides Cass & Yuku nukuáan & Medicinal \\
\hline Helianthemum glomeratum (Lag.) Lag. ex Dunal & Yuku iso & Medicinal \\
\hline Asclepias linaria $\mathrm{Cav}$ & Yuku leche & Medicinal \\
\hline Equisetum hyemale var. affine (Engelm.) A.A. Eaton & Xi'o koo & Medicinal \\
\hline Phytolacca icosandra $\mathrm{L}$ & Yua tiké & Edible, medicinal \\
\hline Tigridia pavonia (L.f.) DC & Tisa'aí & Edible \\
\hline Evolvulus prostratus B.L. Rob & Yuku kueniyu & Medicinal \\
\hline Solanum nigrescens $\mathrm{M}$. Martens \& Galeotti & Tiláxún kuáñú ’ún & Edible, medicinal \\
\hline Galinsoga quadriradiata Ruiz \& Pav & Ndua ntuú & Edible \\
\hline Anoda cristana (L.) Schltdl & Yua tayoó & Edible \\
\hline Solanum dimidiatum $\mathrm{Raf}$ & Íñu burru & Medicinal \\
\hline Acalypha monostachya Cav & Yuku niñi chaa & Medicinal \\
\hline Malva parviflora $\mathrm{L}$ & Yua tayoó stila & Edible, medicinal \\
\hline Brassica rapa $\mathrm{L}$ & Yua martaza & Edible \\
\hline
\end{tabular}


because they are widely known to both healers and a group of plant-savvy older people, they have a name in the Mixtec language (indicating that they have been used by the Mixtec of previous generations), and they are common and more or less equally distributed in all the communities studied. The studied plants have other uses as well, including for play, whistling, forage, scouring pad, ornamental, soap, and decorative-religious. However, analyses of these alternate uses were not included here because the citations were very low.

The interviews, in Spanish or Mixtec, were conducted in people's homes during the spring and summer of 2019 and 2020. We included 5 to 10 people per community (we did not include healers or their relatives), selecting those who agreed to participate after the objective of the study was explained to them and how long the average time of the interview would be. First, we collected basic information about the person (name, age, sex, education, religion, and if they had lived outside the municipality for a period greater than six months). Subsequently, information on the plants was collected. For this we toured the backyards with people to find the plants studied, in the case of several plants a dry or fresh specimen was carried, as well as a series of photographs to show them in case of absence near the houses. Our questions focused on evaluating six variables for each of the 17 plants, as specified below.

Variable 1:"Spanish name," for this variable any name in Spanish given for each plant was collected.

Variable 2: "Mixtec name," designed to determine if the person knew the Mixtec name of each plant.

Variable 3: "Edible use," we asked if the plant was edible.

Variable 4: "Employs (edible use)," aimed at discerning if the person currently uses the plant as food.

Variable 5: "Medicinal use," we asked if the person knew any medicinal use of the plant (for what ailment and how to use it).

Variable 6: "Employs (medicinal use)," aimed at identifying if the person currently uses the plant as a medicine.
For variables 4 and 6, we took the last three years as a reference to consider, yes or no). The information we collected was interpreted as yes/presence $=1$ and no/absence $=0$. Our objective was for the interviews to be individual, but in some cases we had no control over this (for example, when a person who did not remember a name called another member of the household to ask him or her, or when a person who was interested in the interview became involved involuntarily). In this context, we include three interviews in which more than one person participated, we consider that they do not bias the evaluation of the person interviewed since the responses of the other people were omitted. With some participants who expressed interest or time availability, we were also able to talk more extensively about the changes in the use and knowledge of plants between generations.

Voucher specimens were deposited in the Herbarium OAX, of the Interdisciplinary Research Center for Integral Development Regional Unit of Oaxaca (CIIDIR-Oaxaca). The scientific nomenclature of plants is based on The Plant List (2013).

To determine the relationship of our variables with age and educational level, we used the Spearman correlation, the Pearson correlation, and the Kendall $\tau$ rank correlation. The Mann-Whitney test and the Student's t-test were used to verify the existence of differences in gender and migration. In the age, gender, and migration groups to be compared, a similar number of participants were included; the differences ranged from zero to three participants (no adjustments were made for statistical analysis). Very general sociocultural aspects were taken into account in the selection of the three age cohorts: 1) young people who are learning in their parents' home (29 years or younger); 2) people with an active family responsibility (30 to 59 years); and 3 ) older adults (60 years or more).

All data were statistically analyzed using jamovi software (The jamovi project 2021) based on R-language (R Core Team 2020). In all the graphs shown in the results, the bars represent the maximum number of plants cited by groupings (migration, sex, and age) for each variable; inside the bar is the mean, and the letters indicate the statistical differences that are specified in each case. 


\section{Results and Discussion}

\section{Edible and Medicinal Use of Mixtec PlantS}

The analysis of the survey plants yielded interesting results. According to previous (and unpublished) data of the selected plants collected with the healers and the elderly, only 11 of the 17 plants were believed to be medicinal (see Table 1). However, in this survey all the plants were cited at least once as medicinal (Table 2). Some of these results must be considered with caution, however, because it is possible that the plant was not actually used by the interviewee, but rather he or she had seen another person using it. In either case, we accepted the answer as affirmative.

The best known species with a local name in Spanish was B. rapa (62 citations), H. inuloides (61 citations), E. hyemale (51 citations), and $S$. nigrescens (33 citations). Less than half of the informants were able to give a Mixtec name for the most cited plant with a Mixtec name ( $T$. bourgaei; 30 citations). The most cited edible plants (edible use) and currently most consumed (employs [edible use]) were B. rapa (with 63 and 57 citations, respectively) and A. cristata (with 53 and 46 citations, respectively) (Fig. 2). The plant most cited as a medicine (medicinal use) and also the most used (employs [medicinal use]) was $H$. inuloides (with 61 and 49 citations, respectively), followed by $E$. hyemale (with 53 and 41 citations respectively) See Table 2.

The survey shows surprisingly that the general, non-specialist population may have a broader knowledge than people with reputations in the community for their high knowledge of plants, such as healers and older people with extensive ethnobotanical knowledge. This feature can have several explanations, however, and must be carefully explored. An illustrative example is T. bourgaei. This plant is not considered medicinal by local healers; however, in the survey this species was cited as medicinal by two people, one of whom mentioned that this plant is used to control diabetes and added information on treatment. Another example is the species $B$. rapa, which was mentioned to maintain good health (for its iron contribution) and as a healing agent. This last use was learned by the person while he was in a neighboring town. Although they are minimal citations, in both cases the knowledge is exogenous to the community; the first species is indicated for a relatively new disease in the community, which may reflect the process of adaption.

The medicinal species $H$. inuloides and $E$. hyemale were the most cited in our survey. Both share the characteristic of being particularly abundant, the former even in disturbed environments. The less used medicinal plants, such as $E$. prostratus and $H$. glomeratum, are less abundant near the communities and the medicinal use is generally related to native worldview treatments, for example, to control and cure "nahual" related symptoms. On the other hand, the most cited and used edible plants are those that are most abundant, growing mainly in the crops of milpa, although the species $L$. racemosa is the least mentioned and used edible plant despite the fact that it may be abundant in the milpa. Possibly the disuse of this plant is related to its organoleptic characteristics (it is tasteless and odorless). Other plants that show low use in relation to their edible citation, such as T. bourgaei and T. pavonia, may be related to the work required to collect them - the first you must climb a tree, and the second you must dig to obtain the bulb.

On the other hand, it is important to note that some edible plants are discussed in the past tense by older people, with phrases such as: "it was eaten," "no one eats it anymore," or "they say it was eaten." This broad group of plants possibly were important emergency foods during food shortages. The decade of the 1970 s was a very important period of change in the municipality, and people who lived before those years experienced periods of considerable food scarcity. Collection of wild plant resources was a critically important activity. Acorns, for example, were essential resources for food processing, but currently they are only consumed by squirrels. At the end of the 1970s, the government supported efforts to improve corn production, including the use of chemical fertilizers, which partially improved food availability.

The medicinal plants that past generations depended upon have also followed a similar path. During the last five years, approximately five prestigious women healers have died, and it appears that they did not pass their knowledge down to friends or family. Currently there are many plants, for example some species of the 
222

ECONOMIC BOTANY

[VOL 75

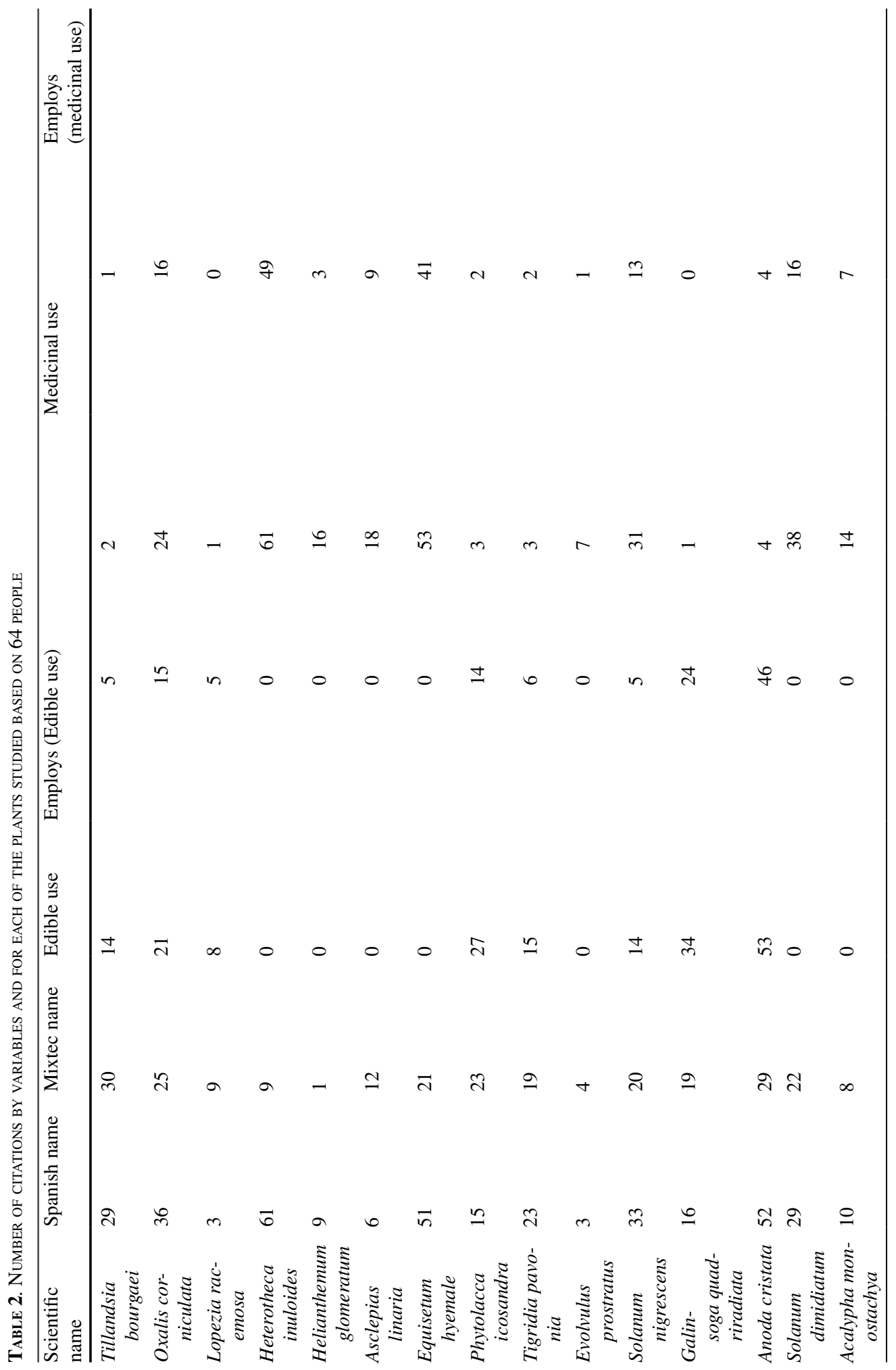




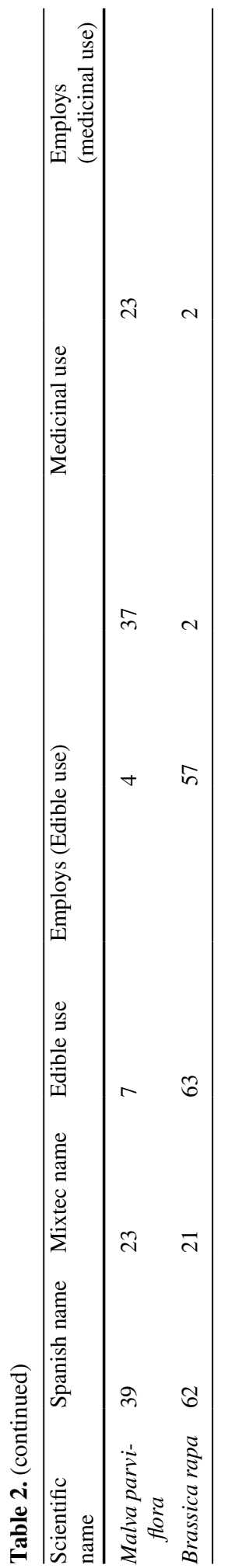

genera Lobelia, Buchnera, and Prosthechea, which are cited as being medicinal but the specific information on their application and/or treatment is unknown. A good example of the process of change in the use of healing plants is the Wigandia urens (Ruiz \& Pav.) Kunth. Previously the leaves of this plant were essential to cover people when they were smeared with a mixture of herbs and bird eggs to cure themselves. For this, the wide leaves of this species were partially passed over the fire to remove the abundant prickly indumentum. The people who have currently maintained this medicinal practice replaced the annoying leaves of $W$. urens by sheets of paper.

\section{Influence of Migration on the KNOWLEDGe and Use of Mixtec Plants}

Migration does not seem to affect the knowledge and use of plants in San Miguel el Grande. Figure 3 shows the number of citations and averages by variables, between people who have migrated in the past and those who have not. People who have not migrated seem to know more "Mixtec names" of plants than people who have migrated (14 vs. 12 citations; 5.45 vs. 3.34 on average), whereas people who have migrated cited more names in Spanish (13 vs. 12 citations; 7.45 vs. 5.47 on average). However, in the Student's t-test for the six variables on knowledge and use of plants according to whether or not the people migrated, none showed significant differences $(p>0.05)$.

The relative unfamiliarity with the Mixtec plant names by the participants who have migrated may be a function of how early in their life they migrated. To illustrate this idea, we present the case of three interviewed elderly women (Fig. 4). We noticed that one of the women who had never left the community knew and used more edible plants.

In Fig. 4, from left to right we can see "Aunt Amelia" (80 years), "Aunt Dorotea" (83 years), and "Aunt Librada" (72 years). The three are from the same community and their homes are no more than $1 \mathrm{~km}$ from each other. Aunt Librada, who did not go to school and who never left her community, is the youngest. She knew three more edible plants than Aunt Amelia and Aunt Dorotea, who are older, who have at least some years 
Fig. 2. Brassica rapa is the best known and most used edible species according to our research. It is cooked with chili and garlic

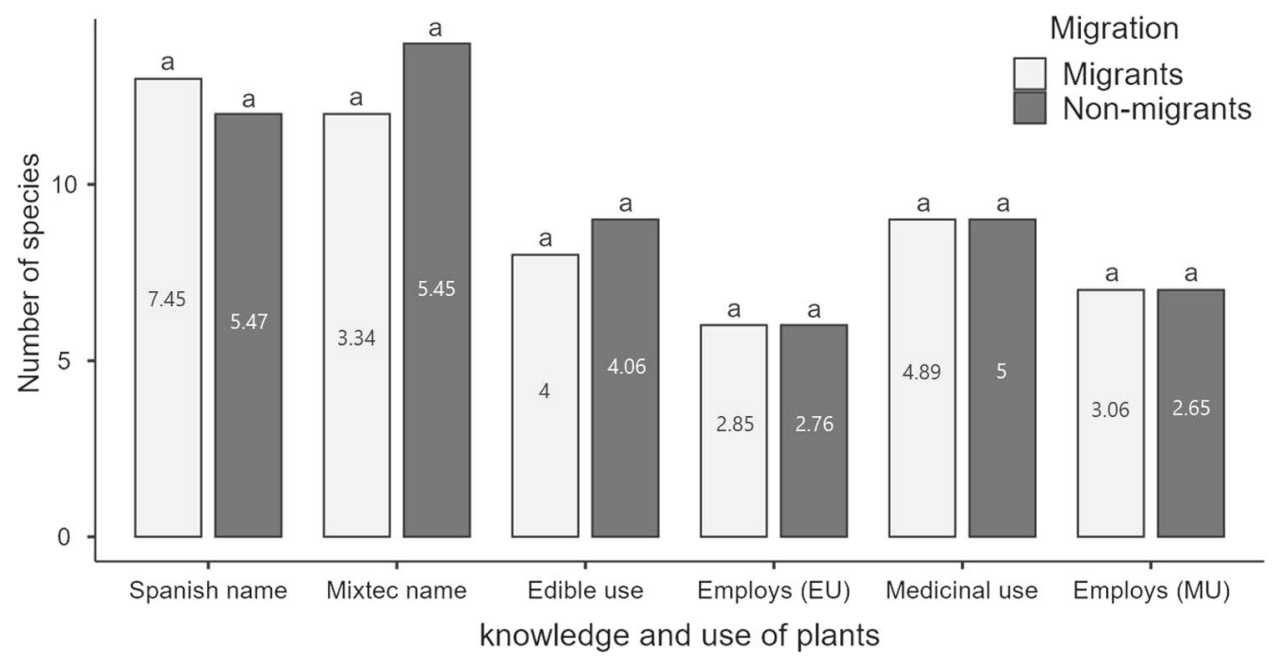

Fig. 3. Knowledge and use of edible and medicinal plants in migrants and non-migrants Mixtec. The equal letters in the same variable indicate a lack of statistical differences using the Student's t-test. The acronyms EU and MU are Edible Use and Medicinal Use, respectively

of primary school, and who migrated respectively from 14 to 25 and from 12 to 23 years of age. Except for the aspects mentioned, we did not find an important difference between migrants and non-migrants. Perhaps the fact that the timing of migration has changed over the years may be affecting TIK. In the past, people migrated at a very young age and stayed for several years or decades; today, people migrate at an older age and for shorter periods, generally between two months and a year. Some studies have shown that when people migrate and settle elsewhere, they tend to conserve the uses of medicinal and edible plants, as well as increase the number of species used based on their availability (Van Andel and Fundiko 2016; Vandebroek and Balick 2012). We were unable to find studies that clearly address the influence of migration on the knowledge and use of plants when people leave an area and later return to the same place. We note that Mixtec who migrate temporarily may have a greater interest in the use of plants, because when they return they 
Fig. 4. Mixtec women from the community of Miguel

Hidalgo, San Miguel el Grande

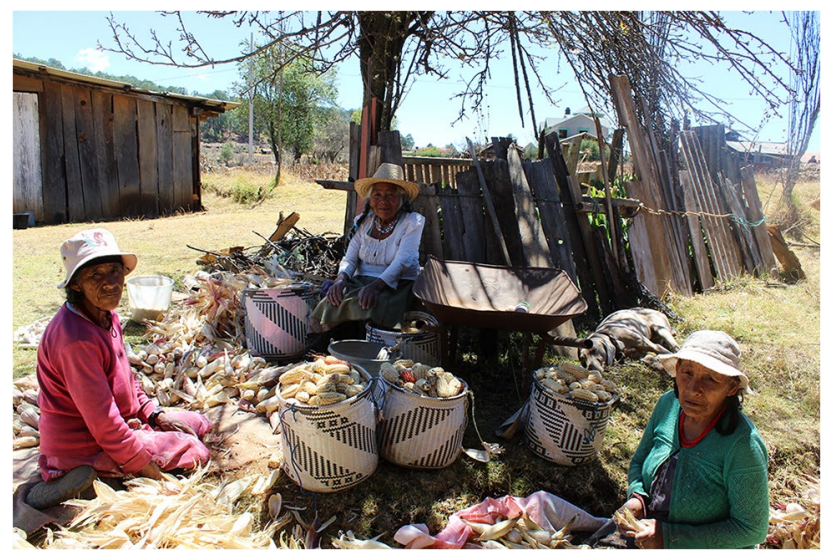

prefer to use both "clean" food and alternative medicine that are not easy to find in the large cities where they migrate. Giovannini et al. 2011 do not exclude the possibility that the Mazatec of Oaxaca may lose and add new knowledge about medicinal plants due to increasing migration. It is important to mention that in migrant Mixtec, the acquisition of technical and perhaps scientific knowledge is notable, especially in those who migrate to the United States and work in the fields. These people usually apply their new knowledge in their crops, in grafts of fruit trees, and care and management of trees.

\section{INFLUENCE OF GENDER ON THE KNOWLEDGE and Use of Mixtec Plants}

We found that, on average, women know more names, more edible and medicinal plants, and also use more plants than men (Fig. 5). However, when we compared the average of all the variables between men and women, only in the variable "Mixtec name" of the plants was a significant difference found (Mann-Whitney U $p=0.035$ ).

Similar results were found in the north coast of the State of Bahia, Brazil, and in the Rarámuri of northern Mexico, where women

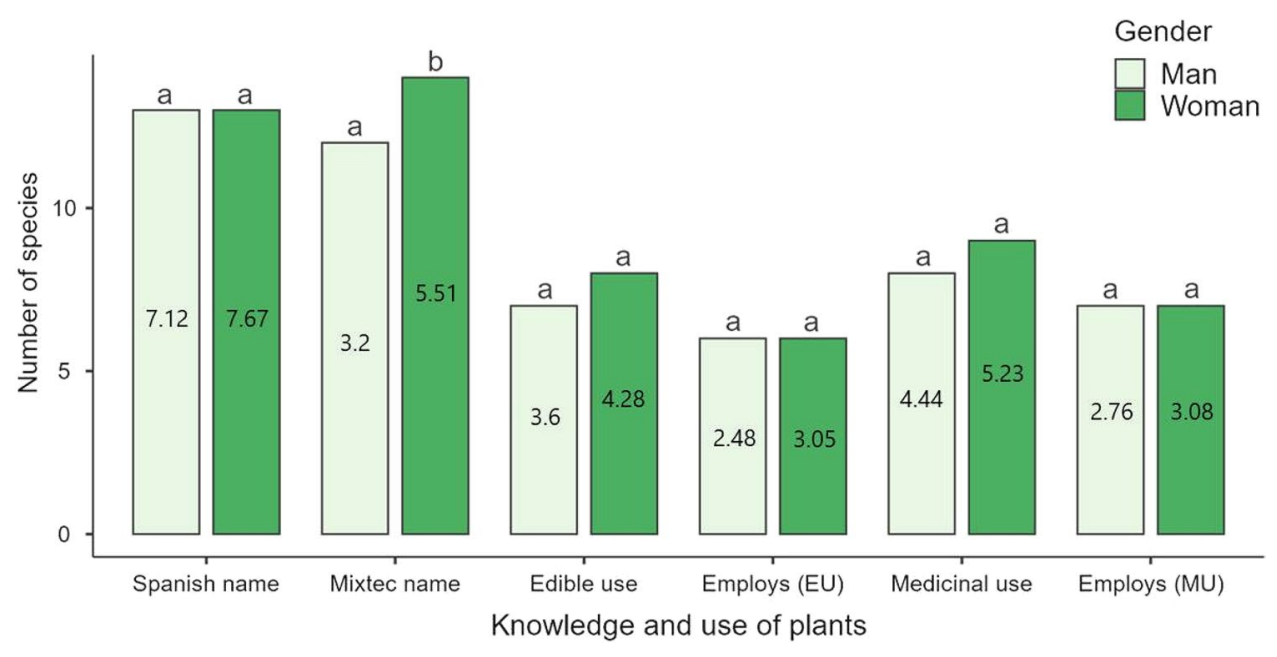

Fig. 5. Knowledge and use of edible and medicinal plants among Mixtec men and women. Equal letters in the same variable indicate a lack of statistical differences using the Mann-Whitney test 
have a greater knowledge of medicinal and edible plants than men (Camou-Guerrero et al. 2008; Tng et al. 2021). The performance of women is surely related to the fact that women are in charge of the health and nutrition of the family (Begossi et al. 2002; Tng et al. 2021). Other studies have attributed the role of women in daily healthcare for why they often have a greater knowledge about plants (Almeida et al. 2012; Silva et al. 2011; Teklehaymanot 2009). Another reason for this division in the Mixtec communities is that women actively participate in cultivation of milpa from which many edible plants and some medicinal plants are obtained. Likewise, previously the Mixtec women of San Miguel el Grande had restricted school attendance. Only men attended school, to learn the necessary skills and then hold public office in the community, leaving women with greater time and connection to the milpa and the forest. Also, women are more likely to have a greater interaction with plants at an early age due to specific female health concerns or because they are mothers. For example, one 20-year-old mother knew more edible and medicinal plants from our sample than other women of the same age who were not mothers.

INFLUENCE OF THE EDUCATIONAL LEVEL ON the Knowledge and Use of Mixtec Plants

The relationship between the level of education and the knowledge and use of the plants was evaluated by means of a Kendall $t$ non-parametric rank correlation. The results were significant for knowledge (variable 3 [Tau $=-0.288$; $p=0.004]$ ) and use (variable 4 [Tau $=-235$; $p=0.021]$ ) of edible plants. As a person's educational level increases, their knowledge and consumption of plants decreases. On the other hand, knowledge (variable 5 [Tau $=-0.163$; $p=0.103]$ ) and use of medicinal plants (variable $6[$ Tau $=-0.184 ; p=0.066])$ did not reflect a significant trend. In relation to plant names, we observed that people who never attended school knew more Mixtec names of plants. The relationship of knowledge of Mixtec names with level of education was significant $(\mathrm{Tau}=-0.517 ; p=0.000)$. However, the relationship between the level of education and the knowledge of names in Spanish did not show significance (Tau $=-0.162 ; p=0.101)$. In general, in San Miguel el Grande, the Mixtec names of plants are being retained by older adults with minimum or no formal education. Educated people, on the other hand, have learned Spanish for the same plants. For example, the citation of names in Spanish in people with a high school education was slightly higher and more diverse than for those without. Literacy has been reported as an important indicator in the decline of ethnobotanical knowledge in various parts of the world (Martínez-Ballesté 2006; Sternberg et al. 2001; Voeks and Leony 2004; Zent 2001). Moreover, in studies carried out elsewhere in Oaxaca, loss of native language was associated with a decrease in ethnobotanical knowledge (Cortés-González 2007; Saynes-Vásquez 2013). Formal education programs and the exclusive use of Spanish in schools in Oaxaca has caused the loss of the local language among the Zapotec culture (Saynes-Vásquez 2013). Similarly for the Mixtec, however, there are additional factors. For example, some parents denied teaching the Mixtec language to their children. This was notable in those who migrated to the cities and suffered discrimination for not speaking the Spanish language well. The phenomenon of discrimination is an important factor in literacy and, by default, the maintenance of ethnobotanical knowledge (Khawaja 2021). During our surveys, we were informed that students with limited resources were discriminated against by other students with better economic conditions for bringing lunches of edible "wild" plants. Children assume that forest plants are "poor people's food," motivating them to not want to know anything about local plants and their traditional food uses. School curricula and programs poorly adapted to the rural context in Oaxaca further contribute to the decline in ethnobotanical knowledge (Giovannini et al. 2011; Saynes-Vásquez 2013). In some rural schools in the high Mixtec subregion, there had been an incentive to seek the link between traditional knowledge and the study programs by including activities that describe traditional ways of life and to include textbooks in the Mixtec language. However, the inclusion of often non-bilingual teachers from more urbanized places, and the adoption of books in the Mixtec language of 
other linguistic variants of the region, is possibly the deficiency of this initiative.

\section{InFLUENCE OF AgE ON THE KNOWLEDGE AND Use of MiXtec Plants}

In relation to age, we found a significant relationship in the knowledge and use of edible and medicinal plants according to the Spearman correlation.

Edible plants: Variable 3 ( $\mathrm{rs}=0.424$; $p=0.004)$ and Variable $4(\mathrm{rs}=0.375 ; p=0.002)$.

Medicinal plants: Variable $5(\mathrm{rs}=0.331$; $p=0.007)$ and Variable $6(\mathrm{rs}=0.332 ; p=0.007)$.

According to these results, older people tend to know and use more edible and medicinal plants than younger people. Regarding the names of the plants, there is a very significant tendency for older people to know more Mixtec names than younger people ( $\mathrm{rs}=0.676$; $p=0.000$ ); Knowledge of Spanish names, however, exhibited a non-significant trend (Pearson correlation coefficient: $\mathrm{r}=0.186 ; p=0.140$ ), suggesting that young people are more familiar with Spanish plant names, or that they are learning new names for the same plants.

Age seems to be predictive of ethnobotanical knowledge in this sample, but there are several reasons why this does not necessarily indicate that knowledge is declining in the younger generation. First, knowledge is time contingent, and older people have had a longer time to assimilate ethnobotanical knowledge. Second, older people are likely to have had more experience dealing with illness episodes. And third, older people have different perceptions than younger people of what constitutes useful knowledge in part because their reference points are different (Ayantunde et al. 2008; Hanazaki et al. 2013; Parveen et al. 2007; Voeks and Leony 2004). Part of the last variable was illustrated when we asked the youngest participants about the 17 survey plants. We noticed that they first think about their immediate interaction with the plants; for example, they mentioned playful uses for the species $T$. bourgaei, T. pavonia, and A. cristata, before mentioning any medical or edible use. Playful plant knowledge is in accordance with their stage of development or with their most immediate memory of direct interaction with the plant. A young Mixtec can eat a plant, but the collection and preparation do not correspond directly to it, so the application of knowledge during use is low. On the other hand, due to experience, context, and the reality of aging, it is difficult for elderly people to cite any playful uses for plants, even though they very likely played with them in their childhood. Phillips and Gentry (1993) argue that, not only do people of different ages have predictably different levels of knowledge, but the type of ethnobotanical knowledge they have is also markedly different.

When the data are separated into age cohorts (Fig. 6) - 16-29 years, 30-59 years, and over 60 years of age-pronounced trends can be observed for some variables. Figure 6 shows the maximum number of species cited by variable and cohort, the averages and the statistical differences in relation to the immediate cohort. Most of the variables showed significant differences between the two youngest cohorts (16-29 and 30-59 years). The most evident difference for all the age groups was in terms of knowledge of the Mixtec names of plant. People over 60 years old overall recognized only one additional species with a Mixtec name compared to the group between 30 and 59 years old. The youngest group, however, exhibited the most dramatic drop, with a total of only three species named in the Mixtec language. In terms of average Mixtec names per person, the differences were highly significant between the cohorts (16-29 vs. $30-59$ years; $p=0.000)$ and $(30-59$ vs. over 60 years; $p=0.000$ ).

Young Mixtec people-under the age of 30 (23 study participants)—basically no longer know the Mixtec name of plants. We predict that Mixtec plant language in San Miguel el Grande is eroding precipitously, and with it a storehouse of ethnobotanical knowledge encoded by the ancient Mixtec. In the best of scenarios, including language rescue efforts, plant names may be retained, but just as empty words, with little or no cultural significance. This is already observable in people who still speak Mixtec but have forgotten the names of plants, as well as those who learned the "Mixtec names" of the plants, but never acquired their meanings.

Numerous studies over the past 20 years have discerned an association between decreasing age and decreasing ethnobotanical knowledge (Arévalo-Marín et al. 2015; Hilgert 2001; Oliveira et al. 2020; Srithi et al. 2009). Most authors have connected this decline with the 

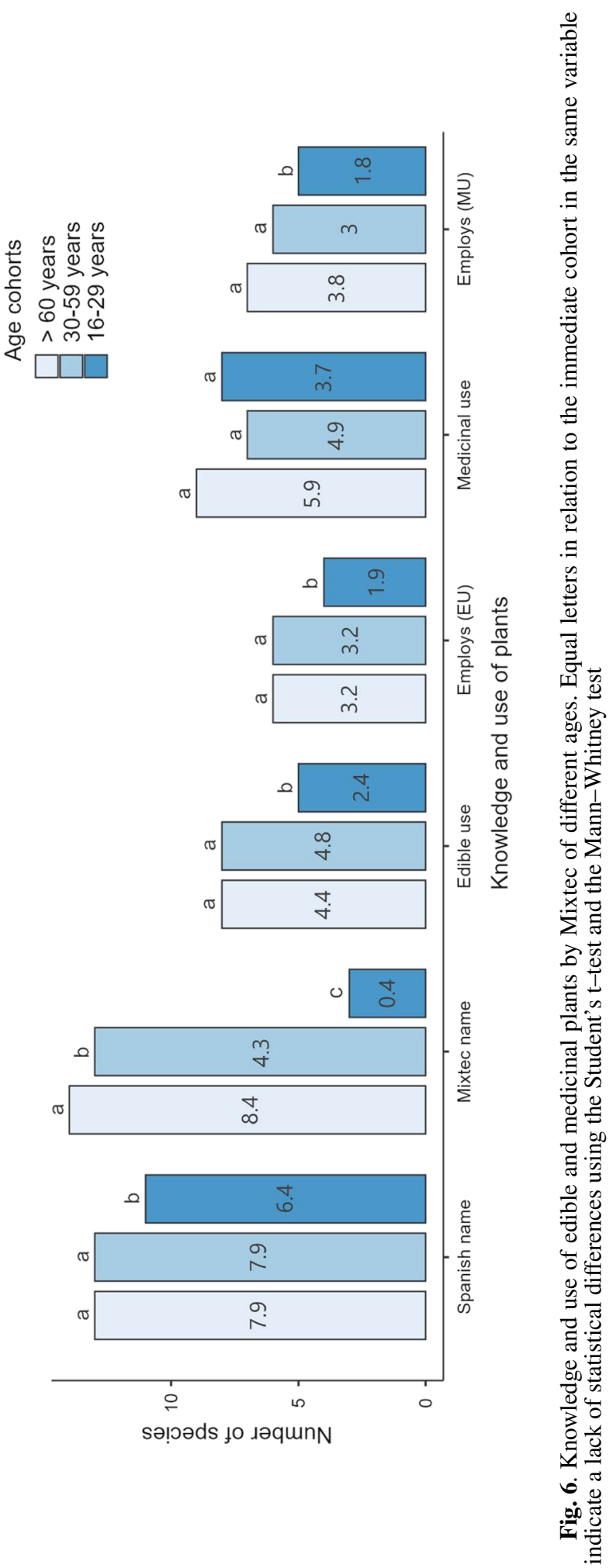
effects of acculturation, modernization, globalization, and loss of knowledge (Benz et al. 2000; Case et al. 2005; Quinlan and Quinlan 2007; Voeks and Leony 2004). However, the case for decreasing knowledge and use of edible and medicinal plants among the young people of San Miguel el Grande is complex. On the one hand, although the young people no longer know the Mixtec names of the plants, they are learning them in Spanish. However, knowing that a plant is useful and using it is not equivalent to knowing the Mixtec name of a plant and its inherent meanings - distribution, toxicity, interspecific relationships, and much more (Aparicio et al. 2021). On the other hand, not only the youngest know and use less edible and medicinal plants. Older people have considerably reduced the use of plants they know (compare variables 3 with 4 and 5 with 6 in Fig. 6). This is important because as disuse increases, it is more likely that knowledge will cease to be transmitted. Two plants from our survey provide useful examples. $E$. hyemale was in the past employed as a scouring pad for washing dishes. But when plastic scrubbers appeared, this use completely disappeared. Knowledge of the medicinal properties of this species is still strong among participants (cited by $82.8 \%$ ), but young people have no idea that it was once used for cleaning. Participant's knowledge of $L$. racemosa, however, is quite different. This edible plant was poorly cited (cited by $18.7 \%$ ) during the survey, but correctly named, even with its name in Mixtec language. When we asked for a use, some people mentioned it as a forage for pigs, and only when we specifically asked if it was edible, did they tell us yes, but it is no longer eaten. In this latter case, there seems to be a conscious disinterest in the edible use of species.

Mixtec names are being replaced by Spanish names, and medicinal species in the wild are being replaced by plants that are easy to grow at home. For example, when we discussed medicinal plants with participants, it was common to cite plants that are easy to grow over those that grow in the wild, with the exception of those species that are very useful because they have had a strong impact on health or those that do not have domestic substitutes. An example for both cases is Laennecia filaginoides, a very useful species due to its effectiveness, and which also has no substitute that exceeds its bitterness, its distinctive characteristic. It is also important to note that today there is more access to industrialized food and government support, thus reducing the need for foraged food plants. There is also greater access to health clinics where people can turn to allopathic medicine. Our findings suggest that species that are particularly useful and easily accessible will continue to be used, although much of their indigenous Mixtec significance no longer prevails.

At the same time, as other authors have noted (Voeks and Leony 2004), young people may be expanding their knowledge and taking advantage of different plants that are available in the community. For example, some people under 40 mentioned medicinal plants such as common plantain, loquat, and bougainvillea that older people never cited as medicine. An interesting example is provided by Eysenhardtia polystachya (Ortega) Sarg., a species that is often used by the general community for the treatment of kidney disorders. The wood of this plant is purchased in small bundles for approximately USD 2.00 in a nearby traditional market. However, the curious thing is that this shrub occurs naturally in the municipality, and older people, including traditional doctors, describe it as a hard wood that has been used as for posts, but they do not describe it as medicine. Clearly, the ethnobotanical significance of this species is changing, but not dying out.

\section{Conclusions}

Our results showed that increasing age, female gender, decreasing formal education, and non-migration are positively correlated with the knowledge and use of plants in San Miguel el Grande, Oaxaca. The results also suggest that socioeconomic level, modernization, acculturation, personal interest such as the search for a healthy diet, or the socio-political systems may have some influence on current Mixtec ethnobotanical knowledge. The people of the region use a wide array of local plants, but a large number have also fallen into disuse. In the past, for instance, some grasses were used for the roofing of houses, and this knowledge is part of the memory of elders, but young people under the age of 30 have never seen houses with grass roofs. Also, some uses are more important 
today, but the knowledge related to traditional uses is no longer useful. For example, we asked five men between 23 and 45 years of age who cut wood for various purposes: What is the recommended date to cut a tree and obtain quality wood? All agreed that there is no specific date, but the oldest Mixtec had the moon phase in mind for this task because it quantitatively affected the quality of the wood. Similarly, some agaves (Agave spp.) previously had more than a dozen uses, but today about three uses are the most important, and two of these are possibly negatively affecting the species.

Knowledge and use of plants is dynamic. Sometimes it stagnates over time, can be forgotten for decades, but then rebuilt in a matter of days. During the current pandemic (Covid-19), for instance, we noticed that many Mixtec reincorporated edible plants into their diet that were no longer being used, and that there was suddenly more interest in local and commercial medicinal plants. But this is not the only time that this occurred in San Miguel el Grande. Some other episodes in the past such as frosts, locust plagues, droughts, and agrarian conflicts, have forced San Miguel residents to reconnect with the forest. It will be necessary to observe in more detail the changing behavior of ethnobotanical knowledge in San Miguel el Grande in the face of an accelerated process of urbanization and acculturation. For now, we have presented a current panorama of a sample of plants that seem to be in the process of transition and adaptation.

\section{Acknowledgments}

The authors wish to thank all the Mixtec who contributed their traditional knowledge for this research. We thank the "tías" from the Hidalgo community for their kind permission to publish the photograph where they appear. We also thank Herbario-Oax for receiving our plants and preparing the labels for them.

\section{Literature Cited}

Aguilar-Santelises, R. and R. F. del Castillo. 2015. Demographic and socio-economic determinants of traditional plant knowledge among the Mixtecs of Oaxaca, Southern Mexico. Human Ecology 43: 655-667.
Albino-García, C., H. Cervantes, M. López, L. Ríos-Casanova, and R. Lira. 2011. Diversity and ethnobotanical facts of the weeds from Tehuacan-Cuicátlan Valley: San Rafael, Coxcatlan Municipality, Puebla. Revista Mexicana de Biodiversidad 82: 1005-1019.

Albuquerque, U. P., G. T. Soldati, S. S. Sieber, M. A. Ramos, J. C. de Sá, and L. C. de Souza. 2011. The use of plants in the medical system of the Fulni-ô people (NE Brazil): A perspective on age and gender. Journal of Ethnopharmacology 133(2): 866-873.

Almeida, C. F. C. B. R., M. A. Ramos, R. R. V. Silva, J. G. de Melo, M. F. T. Medeiros, T. A. D. S. Araujo, A. L. S. Almeida, E. L. C. Amorim, R. R. D. N. Alves, and U. P. Albuquerque. 2012. Intracultural variation in the knowledge of medicinal plants in an urbanrural community in the Atlantic Forest from Northeastern Brazil. Evidence-Based Complementary and Alternative Medicine 2012: 15. https://doi.org/10.1155/2012/679373.

Aparicio, J. C., R. Voeks, and L. Funch. 2021. Mixtec taxonomy: Plant classification, nomenclature, and identification in Oaxaca, Mexico. Ethnobotany Research and Applications 21(1): 1-13.

Arévalo-Marín, E., J. R. F. Lima, A. R. T. Palma, R. F. P. Lucena, and D. D. Cruz. 2015. Traditional knowledge in a rural community in the semi-arid region of Brazil: Age and gender patterns and their implications for plant conservation. Ethnobotany research and Applications 14: 331-344.

Ayantunde, A. A., M. Briejer, P. Hiernaux, H. M. J. Udo, and R. Tabo. 2008. Botanical knowledge and its differentiation by age, gender and ethnicity in Southwestern Niger. Human Ecology 36(6):881-889.

Begossi, A., N. Hanazaki, and J. Y. Tamashiro. 2002. Medicinal plants in the Atlantic Forest (Brazil): Knowledge, use, and conservation. Human Ecology 30(3):281-299.

Beltrán-Rodríguez, L., A. Ortiz-Sánchez, N. A. Mariano, B. Maldonado-Almanza, and V. Reyes-García. 2014. Factors affecting ethnobotanical knowledge in a mestizo community of the Sierra de Huautla Biosphere Reserve, Mexico. Journal of Ethnobiology Ethnomedicine 10:14.

Benz, B. F., J. Cevallos, F. Santana, J. Rosales, and S. Graf. 2000. Losing knowledge about 
plant use in the Sierra de Manantlan Biosphere Reserve, Mexico. Economic Botany 54:183-191.

Cámara-Leret, R. and J. Bascompte. 2021. Language extinction triggers the loss of unique medicinal knowledge. Proceedings of the National Academy of Sciences 118(24):1-5.

Camou-Guerrero, A., V. Reyes-García, M. Martínez-Ramos, and A. Casas. 2008. Knowledge and use value of plant species in a Rarámuri community: A gender perspective for conservation. Human Ecology 36:259-272.

Cano-Contreras, E. J., A. Medinaceli, O. L. Sanabria-Diago, and A. Argueta. 2015. Código de ética para la investigación, la investigación-acción y la colaboración etnocientífica en América Latina. Revista Etnobiología 13:1-28.

Carbajal-Esquivel, H., J. F. Martinez, J. GarciaPérez, J. A. Reyes-Aguero, L. Yanez-Espinosa, and M. Bonta. 2012. Use value of food plants in the Xi'iuy indigenous community of Las Guapas, Rayon, San Luis Potosi, Mexico. Ethnobiology Letters 3(1):39-55.

Case, R. J., G. Pauli, and D. Soejarto. 2005. Factors in maintaining indigenous knowledge among ethnic communities of Manus Island. Economic Botany 59:356-365.

Cilia-López, V. G., J. R. Aguirre-Rivera, J. A. Reyes-Agüero, and B. I. Juárez-Flores. 2008. Ethnobotany of Heliopsis longipes (Asteraceae: Heliantheae). Boletín de la Sociedad Botánica de México 83:81-87.

Cortés-González, J. J. 2007. Variabilidad intracultural y pérdida del conocimiento sobre el entorno natural en una comunidad zapoteca del sur de México (Nizanda, Oaxaca). Tesis de Maestría. México: Facultad de Ciencias, Universidad Nacional Autónoma de México.

Cox, P. A. 2000. Will tribal knowledge survive the millennium? Science 287:44-45.

Cruz-Pérez, A. L., J. Barrera-Ramos, L. A. Bernal-Ramírez, D. Bravo-Avilez, and B. Rendón-Aguilar. 2021. Actualized inventory of medicinal plants used in traditional medicine in Oaxaca, Mexico. Journal of Ethnobiology and Ethnomedicine 17(7).

Ellen, R. and H. Harris. 2000. Introduction. In: Indigenous environmental knowledge and its transformations: Critical anthropological perspectives, eds., R. Ellen, P. Parkes, and A. Bicker, 1-33. Amsterdam: Harwood Academic Publishers.

Estomba, D., A. Ladio, and M. Lozada. 2005. Medicinal wild plant knowledge and gathering patterns in a Mapuche community from North-Western Patagonia. Journal of Ethnopharmacology 103:109-119.

Estrada-Castillón, E., B. E. Soto-Mata, M. Garza-López, J. T. Villarreal-Quintanilla, J. Jiménez-Pérez, M. Pando-Moreno, J. Sánchez-Salas, L. Scott-Morales, and M. Cotera-Correa. 2012. Medicinal plants in the southern region of the state of Nuevo León, México. Journal of Ethnobiology and Ethnomedicine 8:45.

Eyssartier, C., A. L. Ladio, and M. Lozada. 2008. Cultural transmission of traditional knowledge in two populations of Northwestern Patagonia. Journal of Ethnobiology and Ethnomedicine 4:25.

García, E. 2004. Modificaciones al sistema de clasificación climática de Köppen, 5ta edición. México: Universidad Nacional Autónoma de México.

Giovannini, P., V. Reyes-Garcia, A. Waldstein, and M. Heinrich. 2011. Do pharmaceuticals displace local knowledge and use of medicinal plants? Estimates from a crosssectional study in a rural indigenous community, Mexico. Social Science \& Medicine 72(6):928-936.

Gómez-Baggethun, E. and V. Reyes-García. 2013. Reinterpreting change in traditional ecological knowledge. Human Ecology 41(4):643-647.

Hanazaki, N., D. F. Herbst, M. S. Marques, and I. Vandebroek. 2013. Evidence of the shifting baseline syndrome in ethnobotanical research. Journal of Ethnobiology and Ethnomedicine 9:75.

_— - J. Y. Tamashiro, H. F. Leitão-Filho, and A. Begossi. 2000. Diversity of plant uses in two Caiçara communities from the Atlantic Forest coast, Brazil. Biodiversity \& Conservation 9:597-615.

Harrison, K. D. 2008. When languages die: The extinction of the world's languages and the erosion of human knowledge. Oxford, United Kingdom: Oxford University Press.

Hilgert, N. I. 2001. Plants used in home medicine in the Zenta River basin, Northwest 
Argentina. Journal of Ethnopharmacology 76(1):11-34.

INALI (Instituto Nacional de Lenguas Indígenas). 2010. Programa de Revitalización, Fortalecimiento y Desarrollo de las Lenguas Indígenas Nacionales 2008-2012. México: Diario Oficial de la Federación.

INEGI (Instituto Nacional de Estadística y Geografía). 2015. Catálogo de claves de entidades federativas, municipios y localidades.

- 2010. Censo de población y vivienda. México. ——. 2005. Geoestadístico municipal.

ISE (International Society of Ethnobiology). 2006. International Society of Ethnobiology Code of Ethics (with 2008 additions). http:// ethnobiology.net/code-of-ethics/.

Khawaja, M. 2021. Consequences and remedies of Indigenous language loss in Canada. Societies 11(3):8. https://doi.org/10.3390/soc11 030089.

Krauss, M. 1992. The world's languages in crisis. Language 68(1):4-10.

Lozada, M., A. H. Ladio, and M. Weigandt. 2006. Cultural transmission of ethnobotanical knowledge in a rural community of northwestern Patagonia, Argentina. Economic Botany 60(4):374-385.

Martínez-Ballesté, A., C. Martorell, and J. Caballero. 2006. Cultural or ecological sustainability The effect of cultural change on Sabal palm management among the lowland Maya of Mexico. Ecology and Society 11(2):27.

Oliveira, R. L., L. F. Almeida, V. Scudeller, and R. Barbosa. 2020. Traditional botanical knowledge variation between gender and age in a Makuxi community in Roraima savanna, northern Brazilian Amazonia. Ethnoscientia $5(1): 12$.

Parveen, B. U., S. Roy, and A. A. Kumar. 2007. Traditional uses of medicinal plants among the rural communities of Churu district in the Thar Desert, India. Journal of Ethnopharmacology 113:387-399.

Pascual-Mendoza, S., A. Saynes-Vásquez, and A. Pérez-Herrera. 2021. Traditional knowledge of edible plants in an indigenous community in the Sierra Norte of Oaxaca, Mexico. Plant Biosystems-An international journal dealing with all aspects of plant biology. https://doi.org/10.1080/11263504. 2021.1887956 ( 12 March 2021).

Phillips, O. and A. H. Gentry. 1993. The useful plants of Tambopata, Peru: II. Additional hypothesis testing in quantitative ethnobotany. Economic Botany 47(1):33-43.

Quinlan, M. B. and R. J. Quinlan. 2007. Modernization and medicinal plant knowledge in a Caribbean horticultural village. Medical Anthropology Quarterly 21:169-192.

R Core Team (2020). R: A language and environment for statistical computing. (Version 4.0) [Computer software]. Retrieved from https://cran.r-project.org. (R packages retrieved from MRAN snapshot 2020-08-24).

Saynes-Vásquez, A., J. Caballero, J. Meave, and F. Chiang. 2013. Cultural change and loss of ethnoecological knowledge among the Isthmus Zapotecs of Mexico. Journal of Ethnobiology and Ethnomedicine 9(40).

- - H. Vibrans, F. Vergara-Silva, and J. Caballero. 2016. Intracultural differences in local botanical knowledge and knowledge loss among the Mexican Isthmus Zapotecs. PLoS ONE 11(3):e0151693. https://doi.org/ 10.1371/journal.pone.0151693.

Silva, F. S., M. A. Ramos, N. Hanazaki, and U. P. Albuquerque. 2011. Dynamics of traditional knowledge of medicinal plants in a rural community in the Brazilian semi-arid region. Revista Brasileira de Farmacognosia 21(3):382-391.

Smith-Oka, V. 2008. Plants used for reproductive health by Nahua women in northern Veracruz, Mexico. Economic Botany 62:604-614.

Srithi, K., H. Balslev, P. Wangpakapattanawong, P. Srisanga, and C. Trisonthi. 2009. Medicinal plant knowledge and its erosion among the Mien (Yao) in northern Thailand. Journal of Ethnopharmacology 123(2):335-342.

Sternberg, R. J., C. Nokes, P. W. Geissler, R. Prince, F. Okatcha, D. Bundy, and E. Grigorenko. 2001. The relationship between academic and practical intelligence: A case study in Kenya. Intelligence 29(5):401-418.

Teklehaymanot, T. 2009. Ethnobotanical study of knowledge and medicinal plants use by the people in Dek Island in Ethiopia. Journal of Ethnopharmacology 124(1):69-78. 
The jamovi project (2021). jamovi. (Version 1.6) [Computer Software]. Retrieved from https:// www.jamovi.org.

The Plant List. 2013. Available at: http://www. theplantlist.org/ (20 April 2021).

Tng, D. Y. P., D. M. G. Apgaua, M. M. D. Lisboa, and C. N. El-Hani. 2021. Gender differences in plant use knowledge within a traditional fishing community in northeastern Brazil. Ethnobotany Research and Applications 21:1-36.

Van Andel, T. and M. C. C. Fundiko. 2016. The trade in African medicinal plants in Matonge-Ixelles, Brussels (Belgium). Economic Botany 70(4):405-415.

Vandebroek, I. 2010. The dual intracultural and intercultural relationship between medicinal plant knowledge and consensus1. Economic Botany 64(4):303-317.

Vandebroek, I. and M. J. Balick. 2012. Globalization and loss of plant knowledge:
Challenging the paradigm. PLoS ONE 7(5):e37643. https://doi.org/10.1371/journ al.pone.0037643.

Voeks, R. A. 2018. The ethnobotany of Eden: Rethinking the jungle medicine narrative. Chicago: University of Chicago Press.

and A. Leony. 2004. Forgetting the forest: Assessing medicinal plant erosion in eastern Brazil. Economic Botany 58:294-306.

Zent, S. 2001. Acculturation and ethnobotanical knowledge loss among the Piaroa of Venezuela, a demonstration of a quantitative method for the empirical study of traditional environmental knowledge change. In: On biocultural diversity, inking language knowledge, and the environment, ed., L. Maffi, 190-211. Washington, D.C.: Smithsonian Institution Press. 